\title{
Identifying active compounds of soursop ethanolic fraction as $\alpha$-glucosidase inhibitor
}

\author{
Eko Mugiyanto*1, Agung Nur Cahyanta ${ }^{2}$, I Made Agus Sunadi Putra ${ }^{3}$, \\ Siswa Setyahadi ${ }^{4}$, Partomuan Simanjuntak ${ }^{5}$ \\ ${ }^{1}$ Department of Pharmacy, Faculty of Health Sciences, Universitas Muhammadiyah Pekajangan \\ Pekalongan \\ ${ }^{2}$ Department of Pharmacy, STIKES Bhamada Slawi \\ ${ }^{3}$ Department of Pharmacology, Universitas Mahasaraswati \\ ${ }^{4}$ Department of Biotechnology, Indonesian Agency for the Assessment and Application of \\ Technology \\ ${ }^{5}$ Department of Biotechnology, Indonesian Institute of Sciences
}

\begin{abstract}
Postprandial hyperglycemia is triggered by two enteric proteins ( $\alpha$-amylase and $\alpha$ glucosidase) connected to the brush border of intestinal cells. In diabetic populations, Type 2 Diabetes Mellitus is more prevalent, and $\alpha$-glucosidase inhibition is the suitable therapy for delaying glucose intake after meals. This study was designed to investigate chemical compounds for their potential inhibitory effects on $\alpha$-glucosidase. It employed a spectrophotometric method with p-nitrophenyl- $\alpha$-D-glucopyranose from Saccharomyces cerevisiae as an alphaglucosidase substrate. The ethanolic fraction was acquired from assay- or activity-guided fractionation. The findings showed that the ethanolic fraction of soursop leaves exhibited the most significant inhibitory activity with an $\mathrm{IC}_{50}$ of $0.17 \mu \mathrm{g} / \mathrm{mL}$. The data analysis and active compounds identification were carried out by LC-MS and FT-IR. The active compounds of the resulted mixture comprised of Muricatin C, cis-Reticulatacin-10-one, and 3-Methylquercetin 7-[galactosyl(1->4)-glucoside].
\end{abstract}

Keywords: muricatin, cis-Reticulin, methylquercetin, saccharomyces cerevisiae

*Corresponding author:

Eko Mugiyanto

Department of Pharmacy, Faculty of Health Sciences, Universitas Muhammadiyah Pekajangan

Pekalongan

Email: giyan77@gmail.com 


\section{INTRODUCTION}

Diabetes is a chronic metabolic disorder signified by high blood glucose levels due to insufficient endogenous insulin production from pancreatic beta cells (type 1 diabetes) or impaired insulin secretion and activity (type 2 diabetes). Type 1 diabetes is an autoimmune disorder defined by pancreatic beta-cell dysfunction, whereas type 2 diabetes refers to a gradual increase in resistance and beta-cell dysfunction firmly associated with obesity and lifestyle (Zimmet, 2001). Due to the high incidence of its risk factors, the prevalence of diabetes in developing nations is growing globally and more pronounced. Current estimates show that the illness affects a broader group of adolescents by $69 \%$ from 2010 to 2030 , which is considerably higher compared to $20 \%$ in developed nations (Shaw, 2010).

Glucose metabolism dysfunction is strongly linked to impaired insulin secretion because it creates abnormal levels of plasma glucose. Increased abnormal blood glucose in metabolic diseases is pathogenic (Mugiyanto, 2017). Postprandial hyperglycemia, also known as Glucose Tolerance Disorder (GTG), is a glucose regulatory phase in people with glucose tolerance above the standard range but below the level of type 2 diabetes. GTG is a transitional phase between normal glucose tolerance and type 2 DM. Postprandial hyperglycemia plays a key role in developing diabetic complications, particularly cardiovascular disease. A rapid and substantial increase in glycemia typifies the postprandial phase (Ceriello, 2005).

One of the fundamental considerations in postprandial hyperglycemia is rapid glucose intake in the intestine, where $\alpha$-glucosidase hydrolyzes starch and oligosaccharides (Quezada-Calvillo, 2007). $\alpha$-glucosidase is an enzyme present in the intestinal brush border responsible for breakdowns of oligosaccharides (e.g., maltose, maltotriose, and dextrin) that produce monosaccharides (e.g., glucose, galactose, and fructose), which are rapidly absorbed in the small intestinal wall. Consequently, to suppress $\alpha$-glucosidase activity is the recommended approach for the management of postprandial hyperglycemia (Borges de Melo, 2006).

Diabetes management uses three groups of drugs. The first group is sulfonylureas, such as glibenclamide, glinides, insulin analogs, glucagon-like peptide 1 (GLP-1), and dipeptidyl peptidase-IV (DPP-IV) inhibitors, which promote the accessibility of endogenous insulin belonging to this group. The first two group members are pancreatic sulfonylurea receptors that boost the secretion of insulin. On the other side, GLP-1 agonists and DPP-IV inhibitors operate on tiny intestine ileal cells. The second group raises the sensitivity of insulin, including thiazolidinediones-i.e., agonists of the Peroxisome proliferator-activated gamma receptor (PPAR) and biguanide-methane. The third group is made up of $\alpha$-glucosidase inhibitors like acarbose, which operates by decreasing the digestion and bioavailability of polysaccharides (Chehade, 2000). All available therapies have limited efficacy, restricted tolerability, specific side effect mechanisms, or the combination thereof (Moller, 2001).

The World Health Organization (WHO) claims that more than $80 \%$ of the world's total population depend on traditional medicines. It also acknowledges that traditional medicines are not only a therapy that is accessible and affordable but also a culture that many local individuals believe. It exists as an almost universal behavior to suppress the development of chronic noninfectious disorders amid the rising health and hygiene expenses (Anonymous, 2008). Vegetable crops and medicinal products are currently the basis of many contemporary medicinal products for treating different illnesses. The significance of natural products for drug discovery in the future is evident: new pharmacologically active natural products will continue to support as lead compounds for drug development and are biochemical markers for pharmacological and biochemical process discovery (Soumya, 2009).

Soursop (Annona muricata), locally known as asguanabana, graviola, Zuurzak, sirsak, coração-da-India, guyabano, or corossol, is an exotic and delicious fruit that is very popular in 
tropical Asia today. It originated in the West Indies, Central America, and Brazil. More than 50 mono-THF acetogenins have been discovered in the seeds and leaves of this species. Recently, some of the main intermediates involved in the biosynthesis of acetogenin have been separated from this species and are known as epomuricenins-A and B, montecristin, cohibins-A and B, pupin- 1 and 2, pupin-3 and 4, muricadienin, and chatenaytrienins-1, 2, and 3, as well as a novel compound called sabadelin, a potentially biogenetic precursor for cis-panatellin (Ivan, 2003).

Annona muricata is a medicinal plant used as a natural remedy for multiple health conditions. Several studies have shown that A. muricata bark and leaf have anti-hypertensive, vasodilatory, and anti-spasmodic (muscle relaxing) activities and cardiovascular effects that slow heart rate. Other properties and activities of A. muricata have been documented through its traditional use as anticancer, antibacterial, antifungal, antimalarial, antimutagenic (cellular protectors), and anticonvulsant, as well as vomiting and uterine stimulants and insecticides. It is also believed to stimulate digestion, be effective for cardiovascular antiviral (to strengthen the heart), febrifuge (to cure fever), vermifuge, pediculicide, and analgesics, and promote proper functioning of the nervous system. Padma et al. (1998) confirm that the ethanolic extract of $A$. muricata has antiviral effects against Herpes simplex virus. A. muricata extract has been reported to exhibit antiparasitic, antirheumatic, astringent, antileishmanial, and cytotoxic effects. A. muricata has also been proven effective against multi-drug resistance (MDR) in cancer cells (Oberlies, 1997). It has been used as medicinal herbs in many parts of the globe where there is traditionally restricted access to formal healthcare. There are several reasons why the use of medicinal plants should be studied. Among which is the potential for herbal remedies to have not only specific therapeutic effects but also toxic side effects (Bailey and Day, 1989).

One method to relieve metabolic disorders in people with diabetes includes taking hypoglycemic oral synthetic drugs. However, long-term use will trigger side effects such as acute hypoglycemia, kidney damage, liver damage, and lactic acidosis (Murray, 2003). Therefore, the use of natural products as natural anti-diabetic drugs seems to be an increased preference among society. Although there have been many previous studies of soursop as an $\alpha$-glucosidase inhibitor, the focus remains on assessing the activity of the extract instead of identifying the active fractions or compounds responsible for the activity. Therefore, in this research, the compounds that inhibit $\alpha$ glucosidase enzyme have been identified.

\section{METHOD}

This experimental study was designed to identify which active compound of the secondary metabolite in A. muricata leaf has $\alpha$-glucosidase inhibitor property.

\section{Material}

A. muricata used in this research was from the Jogjakarta region and was confirmed in the herbarium laboratory (LIPI) in Bogor, Indonesia. Acarbose, alpha-glucosidase, and p-NPG were purchased from Sigma-Aldrich. The experiment used the instruments for Fourier TransformInfrared Spectroscopy (FTIR, Shimadzu IR Prestige 21) and Mass Spectrometry-Liquid Chromatography (LC-MS, Mariner Biospectrometry).

The extraction employed a multilevel maceration technique with several solvents and water infusions. Soursop leaf powder was obtained with n-hexane, ethyl acetate, $96 \%$ ethanol, and water. The produced filtrate was evaporated and calculated to measure the percentage of the outcome. Afterward, the ethanolic extract was fractionated by silica gel column chromatography using the eluent $\mathrm{CH}_{2} \mathrm{Cl}_{2}-\mathrm{MeOH}$ with a ratio of (20:1) to (1:1). The fraction exhibiting the highest inhibitory activity against $\alpha$-glucosidase was purified by preparative TLC, resulting in isolates that were further identified by IR spectra and LC-MS. 
The $\alpha$-glucosidase assay was prepared following the procedure introduced in Oki et al. (1999) with few modifications. As for the inhibitory activity assay, it was based on the reaction of $\alpha$-glucosidase to the substrate p-nitrophenyl- $\alpha$-D-glucopyranoside (p-NPG). A total of $250 \mu \mathrm{L}$ sample with various concentrations were added with $250 \mu \mathrm{L}$ of p-NPG and then incubated at $37^{\circ} \mathrm{C}$ for 5 minutes. Afterward, the sample was added with $250 \mu \mathrm{L}$ of the $\alpha$-glucosidase enzyme and incubated at $37^{\circ} \mathrm{C}$ for 15 minutes. After the incubation, the sample was added with $500 \mu \mathrm{L}$ of $\mathrm{Na}_{2} \mathrm{CO}_{3}$ to stop enzymatic reaction. The absorbance was measured in a UV-Vis spectrophotometer at a wavelength of $413 \mathrm{~nm}$. The formula and procedure of the experiment are presented in Table I.

Table I. The assay system to evaluate the inhibitory activities against $\alpha$-glucosidase

\begin{tabular}{lcccc}
\hline & $\begin{array}{c}\text { Blank } \\
(\mu \mathrm{L})\end{array}$ & $\begin{array}{c}\text { Blank } \\
\text { Control } \\
(\mu \mathrm{L})\end{array}$ & $\begin{array}{c}\text { Sample } \\
(\mu \mathrm{L})\end{array}$ & $\begin{array}{c}\text { Sample } \\
\text { Control }(\mu \mathrm{L})\end{array}$ \\
& $\mathrm{B} 1$ & $\mathrm{~B} 0$ & $\mathrm{~S} 1$ & \\
\hline Sample & - & - & 250 & 250 \\
p-NPG & 250 & 500 & 250 & 250 \\
Phosphate buffer & 250 & 250 & - & 250 \\
& Incubation at & $37^{\circ} \mathrm{C}$ for 5 minutes & \\
Enzyme & 250 & - & 250 & - \\
$\mathrm{Na}_{2} \mathrm{CO}_{3}$ & - & 500 & - & 500 \\
& Incubation at $37^{\circ} \mathrm{C}$ for 15 minutes & \\
$\mathrm{Na}_{2} \mathrm{CO}_{3}$ & 500 & - & 500 & - \\
\hline
\end{tabular}

\section{Data Analysis}

Each fraction of the assay was subjected to inhibitory activity test. The absorbances of the blank solution, positive control, and the test solution were measured in a UV-Vis spectrophotometer and then calculated to find the percentage of (antidiabetic) inhibitory activity using the formula below:

$$
\% \text { Inhibition }=\frac{C-S}{S} \times 100 \%
$$

where:

$$
\begin{array}{lll}
\mathrm{C} & = & \text { Absorbance of }(\text { Blank }(\mathrm{B} 1)-\text { Control Blank (B0)) } \\
\mathrm{S} & = & \text { Absorbance of }(\mathrm{S} 1-\mathrm{S} 0)
\end{array}
$$

\section{RESULTS AND DISCUSSION}

$\alpha$-glucosidase belongs to the glycoside hydrolases (GHs) family, which catalyzes the degradation of the glycosidic bond by the retaining or inverting mechanisms of anomeric configuration (Koshland, 2008). Stereochemical inversion of an anomeric position involves a single-step mechanism in which protonation of glycosidic oxygen by acids and clusters are accompanied by a nucleophilic attack of a deprotonated water molecule by bases. Typically, acid and base residues are carboxylic groups of enzymes.

The Annona muricata leaf extract was subjected to $\alpha$-glucosidase inhibition assay. The inhibitory properties of the infusions and the hexane, acetate ethyl, ethanolic, and water extracts of soursop leaf are presented in Table II. 
Table II. The results of the $\alpha$-glucosidase assay of extracts and infusions of Annona muricata

\begin{tabular}{lrl}
\hline Extracts & \multicolumn{1}{c}{$\mathrm{IC}_{50}(\mathrm{ppm})$} \\
\hline n-hexane extract & 67.53 & \pm 3.26 \\
Acetate-Ethyl extract & 277.62 & \pm 17.92 \\
Ethanolic extract & 63.73 & \pm 4.11 \\
Water extract & 1682.76 & \pm 67.45 \\
Infusion & 1934.87 & \pm 91.33 \\
\hline
\end{tabular}

Afterward, column chromatography was performed until a single active compound was found (Table III.).

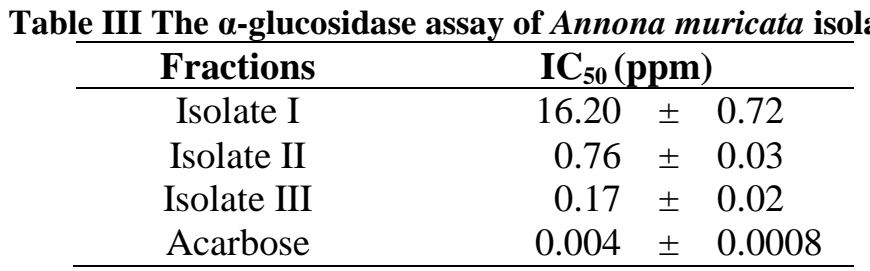

Isolate III was a solid yellow powder with the lowest $\mathrm{IC}_{50}$. The compound was identified by LC-MS with dichloromethane-methanol (20:1) as the eluent that flowed down through the column at a speed of $1 \mathrm{~mL} / \mathrm{min}$

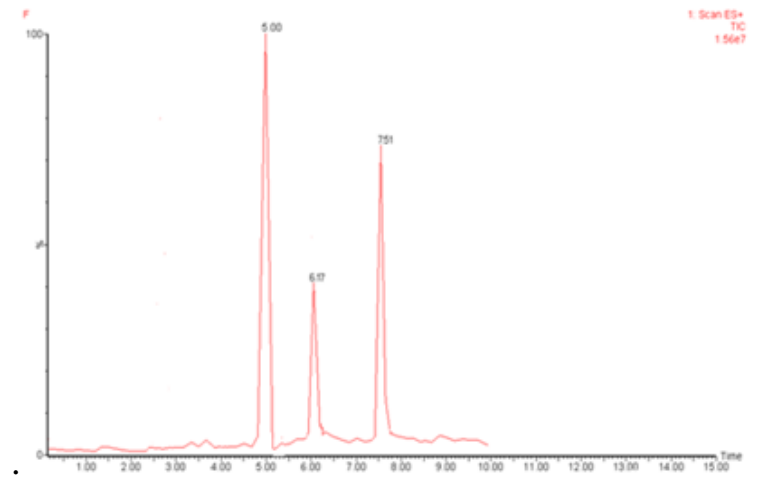

Figure 1. The LC-MS Spectrum of Isolate III Mobile phase: dichloromethane-methanol, 20:1 ratio, at a rate of $1 \mathrm{ml} / \mathrm{minute}$

The LC-MS chromatogram showed that isolate III was not a pure compound because the spectrum had three peaks, as shown in Figure. 1. The $\mathrm{m} / \mathrm{z}$ values for each peak are listed in Table IV.

Each pattern of the LC-MS chromatogram was contrasted with a similar fragmentation pattern of known compounds of A. muricata $\mathrm{L}$.

Table IV. The $\mathbf{m} / \mathbf{z}$ values of the three peaks of isolate III

\begin{tabular}{ccc}
\hline $\begin{array}{c}\text { Peaks of } \\
\text { Isolate } \\
\text { III }\end{array}$ & Rt & $\mathbf{m} / \mathbf{z}(\mathbf{M}+\mathbf{H})$ \\
\hline 1 & 5.00 & 639 \\
2 & 6.17 & 607 \\
3 & 7.15 & 641 \\
\hline
\end{tabular}

At $\mathrm{Rt}=5.00 \mathrm{~min}$, the compound had a molecular weight (MW) of $638 \mathrm{amu}$, A scientific literature (Anonymous, 2016) suggests that there are two recognized compounds with an MW of 
638 amu, namely purpurenin and Muricatin C. Then, the fragmentation pattern of isolate III was compared to that of purpurenin and Muricatin C, as depicted in the literature (Figure 2).

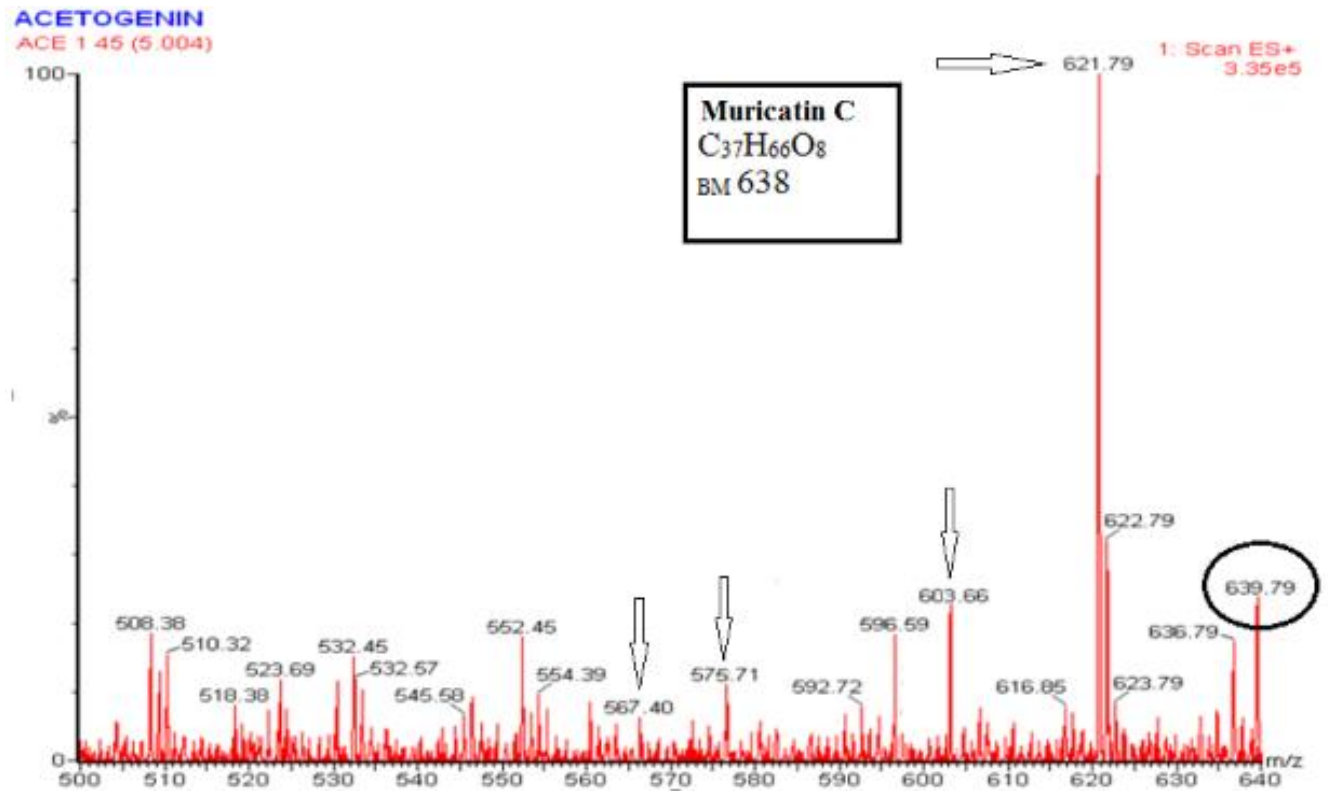

Figure 2. The MS Fragmentation of Isolate III at $\mathrm{Rt}=5.00$ min Fragmentation type: positive $(\mathrm{M}+\mathrm{H})$

The comparison between the fragmentation patterns of the suspected compounds in Isolate III and the reference compounds (from the literature) showed a match with Muricatin $\mathrm{C}$ (acetogenin class). The molecular formula of this compound is $\mathrm{C}_{37} \mathrm{H}_{66} \mathrm{O}_{8}$, with the chemical structure displayed in Figure 3.

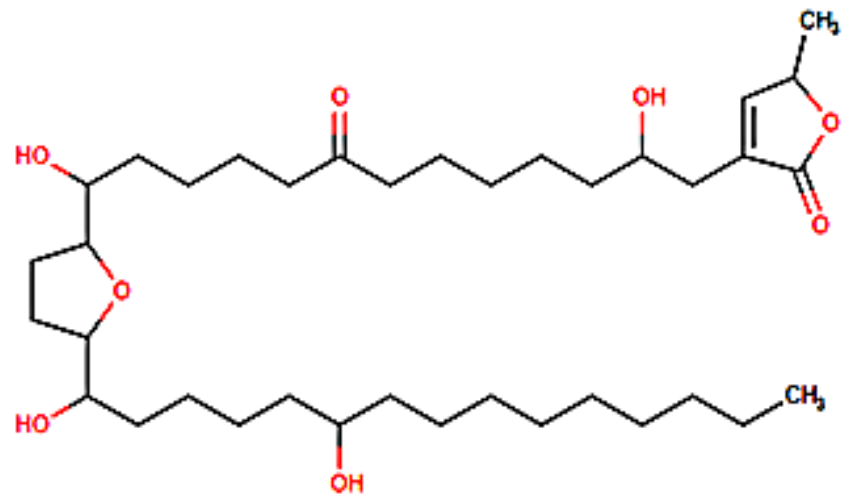

Figure 3. The Chemical Structure of Muricatin C

The MS spectrum at $\mathrm{Rt}=6.17 \mathrm{~min}$ indicates the $\mathrm{m} / \mathrm{z}$ value of $607(\mathrm{M}+\mathrm{H})$ as the base peak, from which an MW of 606 amu was obtained. Then, the MS fragmentation pattern of isolate III at this retention time was compared to that of the reference compound (Anonymous, 2016) (Figure 4). 


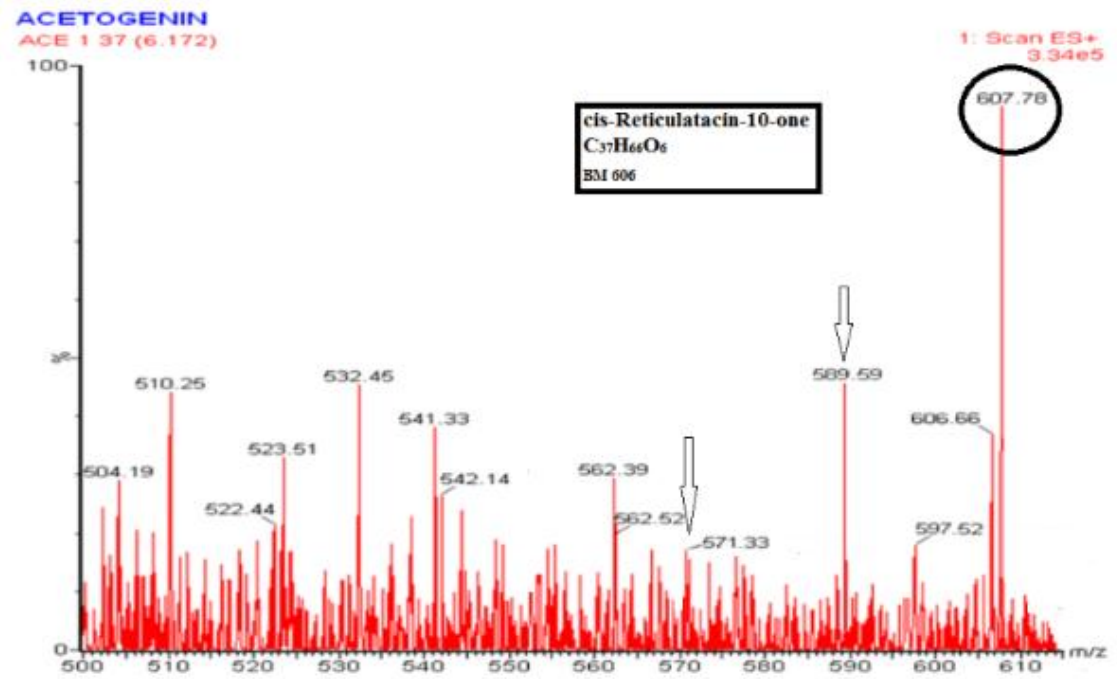

Figure 4. The MS Fragmentation of Isolate III at $\mathrm{Rt}=6.17 \mathrm{~min}$ Fragmentation type: positive $(\mathrm{M}+\mathrm{H})$

At $\mathrm{Rt}=6.17 \mathrm{~min}$, the suspected compound was cis-Reticulatacin-10-one, with a molecular formula of $\mathrm{C}_{37} \mathrm{H}_{66} \mathrm{O}_{6}$ and fragmentation patterns relatively similar to the reference. The chemical structure of the cis-Reticulatacin-10-one is showed in Figure 5.

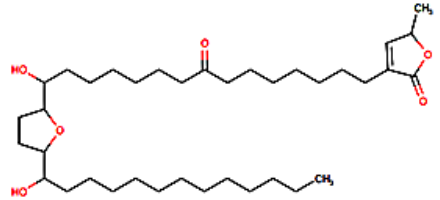

Figure 5. The Chemical Structure of cis-Reticulatacin-10-one

The MS spectrum of Isolate III at $\mathrm{Rt}=7.51 \mathrm{~min}$ showed the $\mathrm{m} / \mathrm{z}$ value of $641(\mathrm{M}+\mathrm{H})$ as the base peak, and a molecular weight (MW) of $640 \mathrm{amu}$ was obtained. Then, any similarities in the fragmentation patterns of the suspected and reference compounds were observed (Figure 6.).

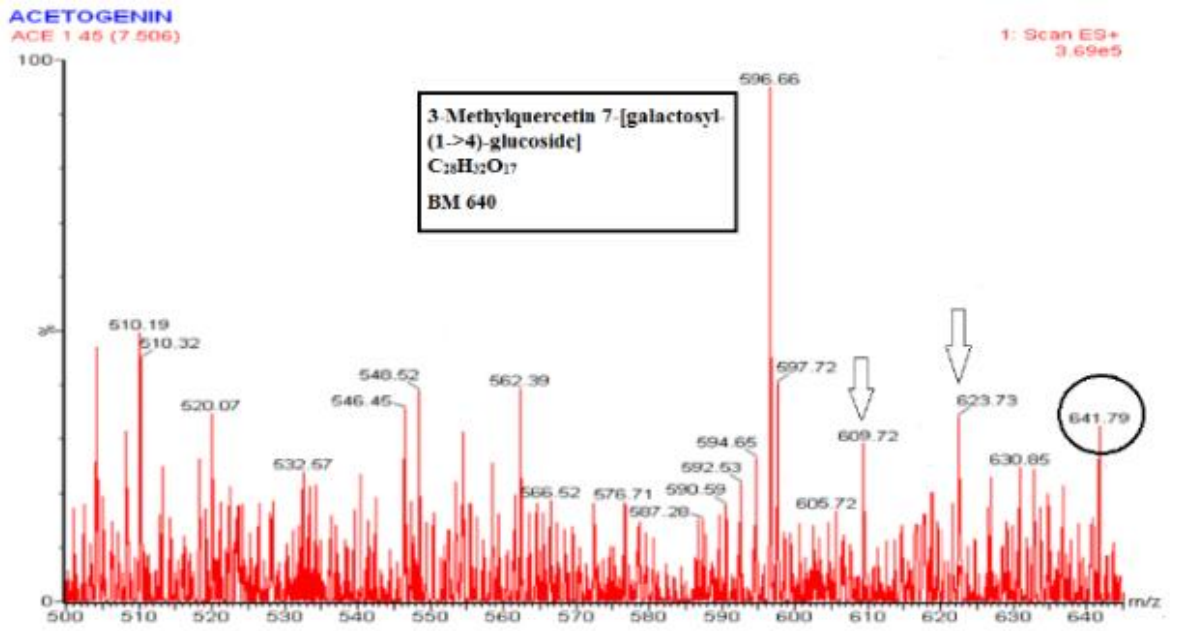

Figure 6. The MS Fragmentation of Isolate III at $\mathrm{Rt}=7.51$ min Fragmentation type: positive $(\mathrm{M}+\mathrm{H})$

At Rt=7.51 min, the suspected chemical compound was 3-Methylquercetin 7-[galactosyl-(1>4)-glucoside], which is a class of flavonoids with the molecular formula $\mathrm{C}_{28} \mathrm{H}_{32} \mathrm{O}_{17}$. The chemical structure is presented in Figure 7.

Identifying active compounds ... (Mugiyanto et al.,) 
<smiles>COc1c(-c2ccc(O)c(O)c2)oc2cc(OC3OC(CO)C(OC4OC(CO)C(O)C(O)C4O)C(O)C3O)cc(O)c2c1=O</smiles>

Figure 7. The Chemical Structure of 3-Methylquercetin 7-[galactosyl-(1->4)-glucoside]

This study found that quercetin from the flavonoid group was an active compound in the test extracts. Flavonoids are common in crops and are a class of natural drugs with significant biological activity. There have been documents of their therapeutic potential against the development of diabetes and their reductive effects on diabetes (Srinivasan et al., 2005). Several publications on flavonoids as an $\alpha$-glucosidase inhibitor have primarily addressed the inhibitory effects of different flavonoids on $\alpha$-glucosidases and its structure-activity interactions (Tadera $e t$ al., 2006).

\section{CONCLUSION}

Isolates are not a single compound responsible for inhibitory activity against $\alpha$-glucosidase $\left(\mathrm{IC}_{50}=0.17 \mathrm{ppm}\right)$. Identification of isolates by LC-MS has indicated that they are a mixture of several compounds. One isolate of Annona muricata had molecular weights of $638 \mathrm{amu}$ at $\mathrm{Rt}=5.00$ $\mathrm{min}, 612 \mathrm{amu}$ at $\mathrm{Rt}=6.17 \mathrm{~min}$, and $640 \mathrm{amu}$ at $\mathrm{Rt}=7.51 \mathrm{~min}$. With these three characteristics, the suspected compounds are Muricatin C, cis-Reticulatacin-10-one, and 3-methyl quercetin 7[galactosyl-(1->4)-glucoside], respectively.

\section{REFERENCES}

Anonymous., 2008, Traditional Medicine. WHO. Available at: http://www.who.int/mediacentre/factsheets/fs134/en/.

Anonymous., 2016, FooDB. Available at: http://foodb.ca/ (Accessed: August 21, 2018).

Bailey, C. and Day, C., 1989, Traditional treatments for diabetes, Diabet Care, 12: 553-554.

Borges de Melo, E., da Silveira Gomes, A.,Carvalho, I., 2006, $\alpha$ - and $\beta$-glucosidase inhibitors: chemical structure and biological activity, Tetrahedroadn, 62(44): 10277-10302.

Ceriello, A. 2005. Postprandial hyperglycemia and diabetes complications: is it time to treat?, Diabetes, 54(1):1-7.

Chehade, JM, Mooradian, AD., 2000, A rational approach to drug therapy of type 2 diabetes mellitus, Drugs, 60(1): 95-113.

Koshland, D.E., J., 2008. Stereochemistry and the mechanism of enzymatic reactions, Biological Reviews, 28: 416-436.

Mugiyanto E, Simanjuntak P, Setyahadi S., 2017, Identifikasi Senyawa Aktif Fraksi Etanol Daun Sirsak (Annona muricata Linn.) Sebagai Inhibitor $\alpha$-AMYLASE, Jurnal Para Pemikir, 6 (2): 131-138.

Ivan A., R., 2003, Medicinal Plant of The World. New York: Springer Science+Business Media.

Moller, D. 2001. New drug targets for type 2 diabetes and the metabolic syndrome, Nature, 414: 821-827.

Murray 2003, Biokimia Harper's. 25th ed. Jakarta: EGC Japan. 
Oberlies, N, Chang CJ, McLaughlin JL., 1997, Structure-activity relationships of diverse Annonaceous acetogenins against multidrug resistant human mammary adenocarcinoma (MCF - 7/Adr) cells, Journal of Medicinal Chemistry. 40(13): 2102-2106.

Oki, T., Matsui, T. and Osajima, Y. 1999. Inhibitory effect of alpha-glucosidase inhibitors varies according to its origin, Journal of Agricultural and Food Chemistry, 47(2): 550-553.

Padma P, Pramod NP, Thyagarajan SP, and Khosa RL., 1998, Effect of the extract of Annona muricata and Petunia nyctaginiflora on Herpes simplex virus. J Ethnopharmacol. 61(1):8183.

Quezada-Calvillo, R, C.C. Robayo-Torres, A.R. Opekun, Sen, P, et al., 2007, Contribution of mucosal maltase-glucoamylase activities to mouse small intestinal starch $\alpha$-glucogenesis, Journal of Nutrition, 137(7): 1725-1733.

Shaw J., 2010, Global estimates of the prevalence of diabetes for 2010 and 2030. - PubMed NCBI. Available at: https://www.ncbi.nlm.nih.gov/pubmed/19896746 (Accessed: February 11, 2018).

Srinivasan, K., Kaul, C. L., and Ramarao, P., 2005, Partial protective effect of rutin on multiple low dose streptozotocin-induced diabetes in mice. Indian Journal of Pharmacology, 37 (5): 327-328.

Soumya, P. R., K. A. Choudary, D. M. Kar, Lopamudra DAS, Avijeet, J., 2009, Traditional Medicinal System - Future Source of New Drugs., International Journal of Pharmacy And Pharmaceutical Science, 1(1): 1-23.

Tadera, K., Minami, Y., Takamatsu, K., and Matsuoka, T., 2006, Inhibition of R-Glucosidase and R- Amylase by Flavonoids. J. Nutr. Sci. Vitaminol. 52: 149-153.

Zimmet, P., K.G, Alberti, J. Shaw., 2001, Global and societal implications of the diabetes epidemic, Nature. Edited by K. G. Alberti, 414(6865): 782-787. 
